\title{
Educational Management vis-à-vis Educational Leadership
}

\author{
Sana Al Haddad \\ Bahrain Teachers College, University of Bahrain
}

\begin{abstract}
This chapter offers the general concepts, definitions, characteristics, brief history and theoretical framework of educational management in comparison to educational leadership. It deliberates the diverse modern educational leadership and management models, and how they might be applied within different educational situations.

It is also an introduction to the concept of educational change, organizational change and the role of educational leadership in change. In addition, it will highlight the most important strategies in managing change, the challenges it faces and ways to overcome resistance to change. This chapter will be for researchers and leaders in the field of education, whether they are school principals, experts or school senior teachers and all those interested in leadership matters from practitioners of both students and administrators.
\end{abstract}

Keywords: Educational leadership, Educational Management, Management Change.

\section{Introduction:}

Due to the successive developments and the many changes, the accumulation of science and the enormous communication revolution as a result of the rapid technological development, the need for effective leadership and management with high efficiency and high quality has become an urgent demand more so now than ever before.

Today, the contemporary educational leadership has vast responsibilities, especially in the field of pupils learning and honing their skills 
This is a limited preview of the chapter.

To read the full-text chapter, get access by purchasing this chapter or consider buying the complete book. If your library has subscription to EBSCOhost, the chapter including other chapters of the book can be accessed through your library.

This chapter is a part of the book, 'Innovations in Educational Leadership and Continuous Teachers' Professional Development' ISBN (paperback): 978-8I-948483-2-5; ISBN (ebook): 978-8I' $948483-3-2$

Book DOI: https://dx.doi.org/ro.46679/isbn9788194848325 Chapter DOI: https://dx.doi.org/I0.46679/isbn978819484832510 
manager implements strategies, measures performance, manages systems. Being a leader is an exciting issue while being a manager is a normal matter, yet management requires some leadership, and great leaders know how to become good managers (Osborne, 2015). Leadership is an essential part of effective management, so all managers should know how to be a leader in addition to how they run.

Although leadership and management differ in their roles, both are very important, organizations that are over-managed but under-led inevitably lose any of their entities and some of their purposes or objectives. Poorly managed organizations with strong leaders whom have surprising appeal, may rise temporarily high and soon collapse shortly thereafter (Bush, 20II). Management is concerned with policies, processes, tools, technical aspects and outputs, while the leadership is concerned with the responsibility and success of the teams and the humanitarian aspects. Management evaluates individuals by their names and according to their old records and current work status. While leadership evaluates individuals based on the ability to do things that cannot be measured because they deal with the future and try to extract the maximum potential of individuals for quality performance and stimulate inventive thinking, so management and leadership are complementary and go hand in hand in all organizations, whatever their level of competence may be.

\section{References:}

Adair, J. (2008).The Best of Adair on Leadership and Management. London: Thorogood Publishing.

Adair, J. (2007). Ioo Greatest Ideas for Effective Leadership and Management. London: Capstone Publishing Ltd.

Armstrong, M. (1997). How to be an even better Manager sed. London: Kogan Page Limited.

Barnes M.A. (2017). Robert Chin and Kenneth D. Benne: Change Management Biography. In: D.B. Szabla., W.A. Pasmore, M.A. Barnes \& A.N. Gipson. (eds). The Palgrave Handbook of Organizational Change Thinkers. Palgrave Macmillan, Cham. 
Bass, B.M (1999).Two Decades of Research and Development in Transformational Leadership. European Journal of Work and organizational change and Development, 8, (I), 9-II.

Bennett, N. (2003). Effective Educational Leadership. London.Paul Chapman Publishing.

Blase, J. EBlase, J.R. (1998). Handbook of Instructional Leadership: How Really Good Principals Promote Teaching and Learning. London: Sage

Brundrett, M. (1998). What Lies Behind Collegiality, Legitimation or Control? An Analysis of the Purported Benefits of Collegial Management in Education.Educational Management Administration \& Leadership 26(3):3053 I 6.

Buckingham, M. (2005). The One Thing you Need to Know. USA: Simon and Schuster Inc.

Bush, T. (20II) Theories of Educational Leadership and Management: Fourth Edition. London: SAGE.

Bush, T, Glover, D. (20II). School leadership models: what do we know? School Leadership and Management.Journal School Leadership $\mho^{2}$ Management Formerly School Organisation, 34(5), 553-571.

Cansoy, R. (2018). The Relationship between School Principals' Leadership Behaviours and Teachers' Job Satisfaction: A Systematic Review.International Education Studies, I2(I), 37-59.

Covey, S, Merrill, A. EMerrill, R. (1994). First Thing First. USA: Simon and Schuster Inc.

Crawford, M. (2009). Fitting to the Heart of the Leadership: Emotion and Educational Leadership. London: Sage Publication Ltd.

Cuban, L. (1988). The Managerial Imperative and the Practice of Leadership in Schools. Albany, NY: State University of New York Press.

Davies, B. (2009). The Essentials of School Leadership. London: Sage Publications Ltd.

Davis, K, ENewstorm, J.W. (1989). Human Behavior at work. New York: McGraw hill book com.

Drucker, P. (I999). Management Challenges for the $2 \mathrm{I}^{\text {st }}$ Century. USA: Harper Collins publishers.

Frazier,L.D. (20I8). A Critical Perspective of Transformational Leadership and Safety Management Practice.Doctoral Dissertation,Walden University.

Goleman, D.,Bayatzis, R. ËMcKee, A.(2002). The new leaders transforming the Art of leadership Into the Science of results. USA: Harvard Business School Press.

Geiner, LE Bhambri, A. (2007), New CEO intervention and dynamics of deliberate change. Strategic Management Journal, Io(I), 67-86

Harris, A. (2004). Distributed leadership and school improvement: leading or misleading? Educational Management Administration Leadership, 32(I), II-24. 
Harris, A., and Chapman, C. (2002). Democratic leadership for school improvement in challenging contexts. International Electronic Journal for Leadership in Learning, 6(9). ISSN i206-9620.

Hopkin, M. (20I4). The Importance of Leadership in Effective Management. Available at:http://leadonpurpuseblog.com

Huber, S (20I0). School Leadership International Perspectives. London: Springer.

Hunter, J. (2004). The World's Most Powerful Leadership Principle. New York: Crown Business.

Ibrahim, A. E Mohamed, M. (20I7). Educational Management, Educational Administration and Educational Leadership: Definitions and General concepts. SAS Journal of Medicine, 3(I2), 326-329.

Judge, T. A., \& Piccolo, R. F. (2004). Transformational and Transactional Leadership: A Meta-Analytic Test of Their Relative Validity. Journal of Applied Psychology, 89(5), 755-768.Available at: https://doi.org/10.1037/00219010.89.5.755

Klenke, K. (2007). Authentic Leadership: A Self, Leader, and Spiritual Identity Perspective. International Journal of Leadership Studies, 3 (I), 68-97.

Leithwood, K. (1994). Leadership for school restructuring. Educational Administration Quarterly, 30(3), 498-518.

Lumby,J. (2009). Distributed Leadership Of Local School Systems. Educational Management Administration and Leadership, 37(3), 310-313.

Miller, TE Miller, J. (2002). Educational Leadership in New Millennium: A Vision for 2020.International Journal of Leadership in Education, 4(2),I8I-I89.

Osborne, Ch. (2015). Essential Managers Leadership. London: Dorling Kindersley Ltd.

Picincu, A. (2019).The Disadvantages of Collegial Management: Available at:https://bizfluent.com/info-8502535-disadvantages-collegial-management.html

Robinson, V.(2007). School Leadership and Student Outcomes: Identifying What Works and Why.Winmalee, NSW: Australian Council of Leaders

Robbins, S. (1998). Organization, Theory Structure, Structure, Design, and Applications. New Jersey: Practice Hall, Englewood Cliffs.

Spiro, J. (20II). Leading Change: Step-by-step. San Francisco: John Wiley \& Son, Inc.

Tringham, K. (2007).Educational gazette, 86(II).Available at: www.edgazette.gov.nz(accessed $5{ }^{\text {th }}$ November 20I5).

West-Burnham, J. (I997), Leadership for learning: reengineering 'mind sets'. School Leadership and Management, I7(2), 23I-243.

York Barr, J. E。 Duke, K. (2004).What Do We Know About Teacher Leadership? Findings from Two Decades of Scholarship. Review of Educational Research, 74(3), 255-316. 
Yukl, G.A. (2002).Leadership in Organizations (5th ed). NJ: Prentice-Hall, Upper Saddle River.

\section{Arabic References:}

Hariri, R. (20I5). Contemporary art in educational leadership. Jordan: Dar Al Nasher, House curriculum for publication and distribution. . (2OII). Managing change in education institutions. Jordan: Dar Al Nasher, House curriculum for publication and distribution. 